\title{
Heating Changes Bio-Schwertmannite Microstructure and Arsenic(III) Removal Efficiency
}

\author{
Xingxing Qiao ${ }^{1,+}$, Lanlan Liu ${ }^{1,2,+}$, Jing Shi ${ }^{3}$, Lixiang Zhou ${ }^{2}$, Yanhan Guo ${ }^{1}$, Yuanying Ge ${ }^{1}$, \\ Wenhua Fan ${ }^{1}$ and Fenwu Liu ${ }^{1, *}$ \\ 1 Environmental Engineering Laboratory, College of Resource and Environment, \\ Shanxi Agricultural University, Taigu 030801, China; qiaoxingxing@stu.sxau.edu.cn (X.Q.); \\ liulanlan@stu.sxau.edu.cn (L.L.); sxaugyh@sxau.edu.cn (Y.G.); sxaugyy@sxau.edu.cn (Y.G.); \\ fanwh@sxau.edu.cn (W.F.) \\ 2 Department of Environmental Engineering, College of Resources and Environmental Sciences, \\ Nanjing Agricultural University, Nanjing 210095, China; lxzhou@njau.edu.cn \\ 3 Analytical Instrumentation Center, Institute of Coal Chemistry, Chinese Academy of Sciences, \\ 27 South Taoyuan Road, Taiyuan 030001, China; shijing@sxicc.ac.cn \\ * Correspondence: liufenwu@sxau.edu.cn; Tel.: +86-354-628-8322 \\ + These authors contributed equally to this work.
}

Academic Editor: Karen Hudson-Edwards

Received: 21 November 2016; Accepted: 11 January 2017; Published: 18 January 2017

\begin{abstract}
Schwertmannite (Sch) is an efficient adsorbent for arsenic(III) removal from arsenic(III)-contaminated groundwater. In this study, bio-schertmannite was synthesized in the presence of dissolved ferrous ions and Acidithiobacillus ferrooxidans LX5 in a culture media. Bio-synthesized Sch characteristics, such as total organic carbon (TOC), morphology, chemical functional groups, mineral phase, specific surface area, and pore volume were systematically studied after it was dried at $105{ }^{\circ} \mathrm{C}$ and then heated at $250-550{ }^{\circ} \mathrm{C}$. Differences in arsenic(III) removal efficiency between $105^{\circ} \mathrm{C}$ dried-sch and $250-550{ }^{\circ} \mathrm{C}$ heated-sch also were investigated. The results showed that total organic carbon content in Sch and Sch weight gradually decreased when temperature increased from $105^{\circ} \mathrm{C}$ to $350^{\circ} \mathrm{C}$. Sch partly transformed to another nanocrystalline or amorphous phase above $350{ }^{\circ} \mathrm{C}$. The specific surface area of $250{ }^{\circ} \mathrm{C}$ heated-sch was $110.06 \mathrm{~m}^{2} / \mathrm{g}$ compared to $5.14 \mathrm{~m}^{2} / \mathrm{g}$ for the $105{ }^{\circ} \mathrm{C}$ dried-sch. Total pore volume of $105{ }^{\circ} \mathrm{C}$ dried-sch was $0.025 \mathrm{~cm}^{3} / \mathrm{g}$ with $32.0 \%$ mesopore and $68.0 \%$ macropore. However, total pore volume of $250{ }^{\circ} \mathrm{C}$ heated-mineral was $0.106 \mathrm{~cm}^{3} / \mathrm{g}$ with $23.6 \%$ micropore, $33.0 \%$ mesopore, and $43.4 \%$ macropore. The arsenic(III) removal efficiency from an initial $1 \mathrm{mg} / \mathrm{L}$ arsenic(III) solution (pH 7.5) was $25.1 \%$ when $0.25 \mathrm{~g} / \mathrm{L}$ of $105^{\circ} \mathrm{C}$ dried-sch was used as adsorbent. However, this efficiency increased to $93.0 \%$ when using $250{ }^{\circ} \mathrm{C}$ heated-sch as adsorbent. Finally, the highest efficiency for arsenic(III) removal was obtained with sch- $250^{\circ} \mathrm{C}$ due to high amounts of sorption sites in agreement with the high specific surface area (SSA) obtained for this sample.
\end{abstract}

Keywords: bio-schwertmannite; specific surface area; pore volume; arsenic(III); adsorption

\section{Introduction}

Groundwater is generally the primary resource for drinking water and irrigation [1], and a large amount of groundwater is used without any pre-treatment. Arsenic contamination of groundwater is an important environmental problem that affects human health and quality of life [2,3]. Arsenic is a highly toxic element that has been categorized as a "Group 1 carcinogen" by the International Agency for Research on Cancer [4]. Long-term exposure to arsenic-contaminated drinking water can cause serious health problems, such as skin damage, bladder cancer, liver cancer, kidney cancer, nasal cancer, and gastric cancer [5]. Because arsenic pollution in groundwater can dramatically raise 
the human risk for cancer and other serious diseases, the World Health Organization (WHO) has admonished countries to limit the As concentration in drinking water to $10 \mu \mathrm{g} / \mathrm{L}$ [6]. However, high concentrations of arsenic (As $>10 \mu \mathrm{g} / \mathrm{L}$ ) in groundwater are frequently found in China, India, Nepal, Bangladesh, and other countries [3,7-9]. Chakraborti et al. [10] investigated the arsenic contamination of groundwater in Patna district (Bihar, India); the study detected a maximum arsenic concentration of $1466 \mu \mathrm{g} / \mathrm{L}$ and found that $61 \%$ and $44 \%$ of tube-wells contained arsenic at concentrations that exceeded $10 \mu \mathrm{g} / \mathrm{L}$ and $50 \mu \mathrm{g} / \mathrm{L}$, respectively. The concentration of arsenic in groundwater in the Datong Basin (Shanxi, China) usually exceeds the WHO-recommended value $(10 \mu \mathrm{g} / \mathrm{L})$ for drinking water and can reach $1820 \mu \mathrm{g} / \mathrm{L}$ [11]. In the environment, arsenic(III) and arsenic(V) are the most common in water environments. $\mathrm{As}(\mathrm{V})$ is the dominant species in an oxidative environment, whereas arsenic(III) is dominant in a reducing environment [12]. Generally, groundwater is characterized by a relatively high $\mathrm{pH}$ of 7-8.5 [13]. Furthermore, it has also been reported that arsenic(III) is 25-60 times more toxic than $\operatorname{arsenic}(\mathrm{V})[14]$. Therefore, removal of arsenic(III) from groundwater is an important problem for the environmental engineering discipline.

Adsorption technology is one of the most popular methods for the treatment of arsenic(III)containing groundwater. Schwertmannite [15], activated alumina [16], $\mathrm{FeCl}_{3}$-based materials [17], chitosan-functionalized graphene oxide [18], bismuth impregnated biochar [19], calix [4] pyrrole [20], and other adsorbents have been used for arsenic(III) removal. Schwertmannite, which is a poorly crystalline $\mathrm{Fe}(\mathrm{III})$-oxyhydroxy-sulfate mineral whose chemical formula is $\mathrm{Fe}_{8} \mathrm{O}_{8}(\mathrm{OH})_{8-2 x}\left(\mathrm{SO}_{4}\right)_{x}$ $(1<x<1.75)[21,22]$ that acts as a good adsorbent for arsenic(III), has gained increasing attention in recent years [23]. In nature, schwertmannite is commonly found in sulfate-rich environments such as acid sulfate soil or acid mine drainage systems [24-26], and is typified by a "hedgehog-like" or "spherical" morphological shape and porous structure [26,27]. In addition, researchers generally accept that the pores in schwertmannite are connected and form tunnels, and that nearly all $\mathrm{OH}^{-}$groups and one-third of the $\mathrm{SO}_{4}{ }^{2-}$ are adsorbed on the material's surface, with the remaining $\mathrm{SO}_{4}{ }^{2-}$ located in the tunnel structures [28]. In general, the $\mathrm{OH}^{-}$and $\mathrm{SO}_{4}{ }^{2-}$ groups on the schwertmannite surface or in tunnel structures can ligand-exchange with arsenic(III) species, a process that determines the arsenic(III) removal efficiency $[13,29,30]$. Besides occurring naturally, schwertmannite can be produced by different synthesis techniques through biotic and abiotic methods; these are becoming essential for the treatment of arsenic(III)-contaminated drinking water $[15,27]$. Among these synthesis techniques, schwertmannite biosynthesis by Acidithiobacillus ferrooxidans oxidizing $\mathrm{FeSO}_{4}$ solution has been proved to be an attractive approach for the preparation of the material within a short reaction time (48-72 h) under eco-friendly reaction conditions without a strong oxidizer and high temperature, which makes the removal of arsenic(III) from groundwater using bio-schwertmannite shows the great application prospect, especially in developing or less developed countries, because of its low producing cost. Moreover, Liao et al. [13] found that both Freundlich and Langmuir isotherms could be used to describe the adsorption behavior of arsenic(III) on biogenic schwertmannite; a maximum arsenic(III) adsorption capacity of $113.9 \mathrm{mg} / \mathrm{g}$ bio-schwertmannite can be achieved in the $\mathrm{pH}$ range 7-10. The maximum arsenic(III) adsorption capacity of bio-schwertmannite was higher than that of other adsorption materials under similar $\mathrm{pH}$ conditions, such as $1-4 \mathrm{mg} / \mathrm{g}$ for activated alumina [16], $27.1 \mathrm{mg} / \mathrm{g}$ for $\mathrm{FeCl}_{3}$-based materials [17], $64.2 \mathrm{mg} / \mathrm{g}$ for chitosan-functionalized graphene oxide [18], and $15.28 \mathrm{mg} / \mathrm{g}$ for calix pyrrole [4,20]. Therefore, the removal arsenic(III) from groundwater or other contaminated water sources using bio-schwertmannite has great commercial value.

Unfortunately, bio-synthesized schwertmannite particles aggregate too closely because of the extracellular polymeric substances (EPS) of A. ferrooxidans that exist in the biosynthesis systems $[27,31,32]$, thereby reducing the schwertmannite specific surface area (SSA). Previous studies have shown that the SSA of bio-synthesized schwertmannite can vary from $\sim 3$ to $\sim 50 \mathrm{~m}^{2} / \mathrm{g}[15,27,31,33]$. Further improving the SSA of bio-synthesized schwertmannite is an important challenge to the wider use of this material as an adsorbent for arsenic(III) removal from groundwater. The EPS secreted by A. ferrooxidans consists mainly of extracellular lipopolysaccharide and outer membrane 
proteins [34]. In order to remove the EPS from bio-synthesized schwertmannite for increasing the SSA of bio-synthesized schwertmannite, preliminary experiments have attempted to extract the EPS using organic solvents such as ethanol and acetone (the ratio of bio-synthesized schwertmannite weight and organic solvent volume was 1:100). It was found that the SSA of bio-synthesized schwertmannite only increased from 2.98 to 3.85 or $4.73 \mathrm{~m}^{2} / \mathrm{g}$ after ethanol or acetone treatment, respectively. It is well known that organic carbon, such as the EPS of microorganisms, can be effectively removed under high temperature conditions. However, whether heating can improve the SSA of bio-schwertmannite, or result in changes to the bio-schwertmannite microstructure, and changes to the arsenic(III) removal capacity of bio-schwertmannite have not been studied.

The aims of the present study were (1) to investigate bio-synthesized schwertmannite characteristics, such as total organic carbon, morphology, chemical functional groups, mineral phase, specific surface area, and pore volume distribution, as a function of heat treatment at $250-550{ }^{\circ} \mathrm{C}$; and (2) to examine the difference of arsenic(III) removal capacity between $105^{\circ} \mathrm{C}$ dried bio-synthesized schwertmannite and $250-550{ }^{\circ} \mathrm{C}$ heated bio-synthesized schwertmannite.

\section{Materials and Methods}

\subsection{A. Ferrooxidans LX5 and Its Culture}

A strain of iron-oxidizing bacteria, A. ferrooxidans LX5(CGMCC No. 0727), obtained from the China General Microbiological Culture Collection Center was used in this study. The A. ferrooxidans LX5 strain was inoculated in modified $9 \mathrm{~K}$ liquid culture medium with an initial $\mathrm{pH}$ of $\sim 2.50$ [35]. The medium was composed of $\mathrm{FeSO}_{4} \cdot 7 \mathrm{H}_{2} \mathrm{O}(44.2 \mathrm{~g} / \mathrm{L}),\left(\mathrm{NH}_{4}\right)_{2} \mathrm{SO}_{4}(3.5 \mathrm{~g} / \mathrm{L}), \mathrm{Ca}\left(\mathrm{NO}_{3}\right)_{2} \cdot 4 \mathrm{H}_{2} \mathrm{O}(0.0168 \mathrm{~g} / \mathrm{L}), \mathrm{K}_{2} \mathrm{HPO}_{4}$ $(0.058 \mathrm{~g} / \mathrm{L}), \mathrm{KCl}(0.119 \mathrm{~g} / \mathrm{L})$, and $\mathrm{MgSO}_{4} \cdot 7 \mathrm{H}_{2} \mathrm{O}(0.583 \mathrm{~g} / \mathrm{L})$. Then, the culture was incubated at $28^{\circ} \mathrm{C}$ in a rotatory shaker (SHZ-A model, Changzhou Henglong instrument Co., Ltd, Changzhou, China) at $180 \mathrm{r} / \mathrm{min}$ until the ferrous ions in the system were completely oxidized, and after $60 \mathrm{~h}$ was filtered through quantitative filter paper $(\phi 12.5 \mathrm{~cm}$, Jiejie brand, Fushun city Dongyang Industrial and Trading Co., Ltd., Fushun, China) to remove iron-based precipitate. The filtered culture with $\mathrm{pH}$ of $\sim 2.20$ containing $\sim 3 \times 10^{7}$ cells $/ \mathrm{mL}$ of $A$. ferrooxidans $\mathrm{LX} 5$ cells was used for bio-synthesized schwertmannite preparation. All solutions were prepared with deionized water using analytical grade reagents.

\subsection{Preparation of Bio-Synthesized Schwertmannite}

Bio-schwertmannite was prepared using A. ferrooxidans LX5 to bio-oxidize a ferrous ions solution in a custom-designed $25-\mathrm{L}$ bioreactor. In brief, $13.5 \mathrm{~L}$ of solution containing $0.16 \mathrm{~mol} / \mathrm{L}$ ferrous ions (added as $\mathrm{FeSO}_{4} \cdot 7 \mathrm{H}_{2} \mathrm{O}$ ) was dispensed into a bioreactor fitted with an air compressor and temperature controller. The aeration rate and temperature in the bioreactor were controlled at $0.055 \mathrm{~m}^{3} / \mathrm{min}$ and $\sim 28{ }^{\circ} \mathrm{C}$, respectively. A $1.5 \mathrm{~L}$ quantity of $A$. ferrooxidans $\mathrm{LX} 5$ culture prepared as described in Section 2.1 was added into the bioreactor resulting in a bacterial density of $\sim 3 \times 10^{6}$ cells $/ \mathrm{mL}$ in the bioreactor. During the schwertmannite bio-synthesization process, the $1 \mathrm{~mL}$ of solution was withdrawn from the system at $12 \mathrm{~h}$ intervals, filtered through a $0.22 \mu \mathrm{m}$ membrane filter, and analyzed to determine ferrous ions concentration in filtrate using 1,10 phenanthroline method [27]. After $60 \mathrm{~h}$, the ferrous ions were bio-oxidized completely. Then, the cultures were filtered through quantitative filter paper to obtain a suspended reddish-brown precipitate. The precipitate was rinsed twice with distilled water before being dried in a digital vacuum drying oven (GZX-9246MBE model, Shanghai Boxun industry Co., Ltd., Shanghai, China) at $105^{\circ} \mathrm{C}$ to constant weight, after which the residue was ground and passed through a 100-mesh screen (Zhang Xingsha Sieve Factory, Shaoxin, China). The dried residue was characterized using $X$-ray diffraction (XRD) and field-emission scanning electron microscopy (SEM) to confirm that the collected precipitate was schwertmannite. 


\subsection{Bio-Schwertmannite Heating}

Bio-schwertmannite heating was accomplished in a box-type electric resistance furnace (SX-8-10 model, Yingshan State Experimental Equipment Factory, Huanggang, China). Twelve $18 \mathrm{~mL}$ porcelain crucibles were triple-rinsed with deionized water and heated at $550{ }^{\circ} \mathrm{C}$ for $2 \mathrm{~h}$; the crucibles were then cooled in a desiccator to room temperature before use. Then, approximately $2.0000 \mathrm{~g}$ bio-schwertmannite was placed in each crucible, and was weighed and numbered. Three crucibles were assigned randomly to $2 \mathrm{~h}$ heat treatments at 250, 350, 450, or $550{ }^{\circ} \mathrm{C}$. Each treatment was performed in triplicate. After treatment, the heated bio-schwertmannite was cooled and weighed to determine the weight loss of bio-schwertmannite during heating. Samples of untreated bio-schwertmannite and heated bio-schwertmannite were collected for determination of total organic carbon, morphology, chemical functional groups, mineral phase, specific surface area, and total pore volume. The distribution of specific surface area and pore volume among micropores $(<2 \mathrm{~nm}$ diameter), mesopores $(2-50 \mathrm{~nm})$, and macropores $(>50 \mathrm{~nm})$ also was determined. It should be pointed out that the weight loss and total organic carbon concentration of bio-schwertmannite have been determined for each of the triplicates. The morphology, chemical functional groups, mineral phase, specific surface area, and total pore volume have been determined for the mixture of the triplicates.

\subsection{Arsenic(III) Adsorption Efficiency of Heated Bio-Schwertmannite}

The $\mathrm{As}_{2} \mathrm{O}_{3}$ was dried in a digital vacuum drying oven for $2 \mathrm{~h}$. A $1000 \mathrm{mg} / \mathrm{L}$ arsenic(III) stock solution was prepared by dissolving dried $\mathrm{As}_{2} \mathrm{O}_{3}$ in $\mathrm{NaOH}$ solution, and was stored at $4{ }^{\circ} \mathrm{C}$ before use. Before the arsenic(III) adsorption experiment, a solution containing $1.0 \mathrm{mg} / \mathrm{L}$ arsenic(III) was prepared by diluting the stock solution. Each solution was adjusted to $\mathrm{pH} \sim 7.50$ by dropwise addition of $0.1 \mathrm{~mol} / \mathrm{L} \mathrm{HCl}$ or $\mathrm{NaOH}$. Arsenic(III) adsorption was determined by adding $10 \mathrm{mg}$ of untreated, $250{ }^{\circ} \mathrm{C}$, or $550{ }^{\circ} \mathrm{C}$ heated bio-schwertmannite to $100 \mathrm{~mL}$ capped plastic bottles (inner diameter $46 \mathrm{~mm}$ ), each containing $40 \mathrm{~mL}$ solution (initial $1.0 \mathrm{mg} / \mathrm{L}$ arsenic(III)). The untreated, $250{ }^{\circ} \mathrm{C}$, or $550{ }^{\circ} \mathrm{C}$ heated bio-schwertmannite concentration in arsenic(III) adsorption systems was $0.25 \mathrm{~g} / \mathrm{L}$. All plastic bottles were shaken in a rotary shaker (HZQ-F160 model, Harbin, China) at $28{ }^{\circ} \mathrm{C}$ and $180 \mathrm{r} / \mathrm{min}$. It is noted that $4 \mathrm{~h}$ is adequate for arsenic(III) to reach adsorption equilibrium on bio-schwertmannite [13]. After $4 \mathrm{~h}$ adsorption, the solution from different treatments was filtered through a $0.45 \mu \mathrm{m}$ membrane and analyzed for arsenic(III). Each treatment was conducted in triplicate.

It is noted that the main aims during arsenic(III) removal experiment in here was to examine the difference of arsenic(III) removal capacity between $105^{\circ} \mathrm{C}$ dried bio-schwertmannite and $250-550{ }^{\circ} \mathrm{C}$ heated bio-schwertmannite. To find the maximum arsenic(III) adsorption capacity of $105^{\circ} \mathrm{C}$ dried bio-schwertmannite or $250-550{ }^{\circ} \mathrm{C}$ heated bio-schwertmannite was not the objective. According to the previous reports form our research group [13,27], $0.25 \mathrm{~g} / \mathrm{L}$ was chosen as the only bio-schwertmannite concentration. This does not mean that dried bio-schwertmannite and heated bio-schwertmannite can adsorb arsenic(III) from groundwater under these low concentrations.

\subsection{Analytical Procedures}

The weight of untreated and heated bio-schwertmannite was measured using an electronic balance (Sartorius BS 124S, Beijing, China) with a precision of $0.0001 \mathrm{~g}$. The surface morphology of untreated or heated bio-schwertmannite was investigated using field-emission scanning electron microscopy (SEM, JSM-7001F, Tokyo, Japan) with an accelerating voltage of $10 \mathrm{kV}$ [35]. The bio-schwertmannite phase was determined using X-ray diffraction (XRD, MiniFlex II, Tokyo, Japan) with a Cu K $\alpha$ X-ray source [35]. Fourier transform infrared (FTIR) spectroscopy (Bruker, Model Tensor 27, Karlsruhe, Germany) was used to characterize various chemical functional groups in untreated and heated bio-schwertmannite [23]. Total pore volume and the specific surface area of bio-schwertmannite were determined by the $\mathrm{N}_{2}$-BET method using a surface area and porosimetry analyzer (Quantachrome, Boynton Beach, USA) [36]. Total organic carbon (TOC) of bio-schwertmannite was analyzed by the 
combustion/non-dispersive infrared (NDIR) method (Multi N/C-3100 model, Analytikjena, Jena, Germany) [37]. Arsenic(III) concentration was determined using a dual-channel atomic fluorescence photometer (AFS-2100, Beijing, China) [38] with a detection limit of $0.01 \mu \mathrm{g} / \mathrm{L}$.

\section{Results and Discussion}

\subsection{Color, Total Organic Carbon (TOC) Content, and Weight Loss of Bio-Schwertmannite}

The color of untreated bio-schwertmannite (bio-schwertmannite dried at $105^{\circ} \mathrm{C}$ ) was reddish-brown, as also found in previous studies [23,39]. However, the color changed from reddish-brown to black when the heating temperature increased and reached $550{ }^{\circ} \mathrm{C}$. The color of bio-schwertmannite began turning black at $250{ }^{\circ} \mathrm{C}$ and was completely black at $350-550{ }^{\circ} \mathrm{C}$. The total organic carbon (TOC) content and weight loss of bio-schwertmannite changed noticeably as the heating temperature varied (Figure 1). This showed that the EPS secreted by A. ferrooxidans and dead A. ferrooxidans cells was removed from bio-schwertmannite during the heating process. The relationship between the heating temperature and the loss of $A$. ferrooxidans cells and the secreted EPS was measured by determining the amount of TOC in bio-schwertmannite after heating treatment (Figure 1a). The initial TOC content in untreated bio-schwertmannite was $1.54 \mathrm{mg} / \mathrm{g}$. The TOC content decreased by $55.2 \%$ in $250{ }^{\circ} \mathrm{C}$ heated bio-schwertmannite and by $89.0 \%-89.6 \%$ in bio-schwertmannite heated at $350-550{ }^{\circ} \mathrm{C}$. Thus, TOC was gradually removed as the heating temperature increased from 105 to $550{ }^{\circ} \mathrm{C}$.
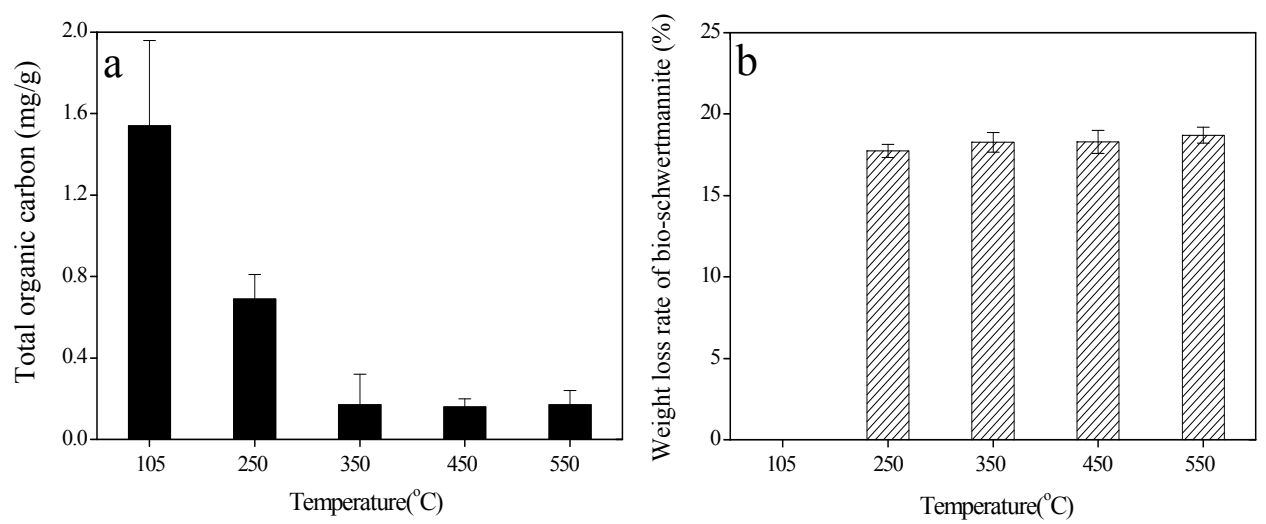

Figure 1. Total organic carbon content (a) and weight loss of bio-schwertmannite (b) before and after heating.

The weight loss of bio-schwertmannite after heating was calculated as a percentage of the initial weight of material dried at $105{ }^{\circ} \mathrm{C}$ (Figure 1b). As shown, the weight loss reached $17.75 \%$ at $250{ }^{\circ} \mathrm{C}$. However, the weight loss increased just from $17.75 \%$ to $18.71 \%$ when the heating temperature increased from 250 to $550{ }^{\circ} \mathrm{C}$. In other words, the weight loss of bio-schwertmannite increased significantly when the heating temperature increased in the range of $105-250{ }^{\circ} \mathrm{C}$ and increased slightly in the range of $250-550^{\circ} \mathrm{C}$. This result was similar to that reported by Sun et al. [40] who found that the weight loss of bio-schwertmannite collected from the Malan mine in Shanxi province, China was $18.12 \%$ when the bio-schwertmannite heating temperature increased from 99 to $535^{\circ} \mathrm{C}$. In addition, Gan et al. [23] synthesized schwertmannite using acidophilic bacterium A. ferrooxidans 23270 with a $\mathrm{FeSO}_{4} \cdot 7 \mathrm{H}_{2} \mathrm{O}: \mathrm{AlPO}_{4}$ ratio of 200:1. They found that the mass of bio-schwertmannite decreased only slightly $(\sim 2 \%)$ when the heating temperature changed from 250 to $550{ }^{\circ} \mathrm{C}$, as observed from the bio-schwertmannite thermal analyses curve. Figure 1 shows conclusively that the removal of EPS and A. ferrooxidans cells by heating contributes little to bio-schwertmannite weight loss because the initial TOC content in untreated bio-schwertmannite was negligible $(1.54 \mathrm{mg} / \mathrm{g})$. Therefore, the significant loss of bio-schwertmannite mass during heating may be related to the loss of chemical functional groups. 


\subsection{Chemical Functional Groups and Phase of Bio-Schwertmannite}

The variation in chemical groups associated with bio-schwertmannite can be observed from the FTIR spectra (Figure 2).

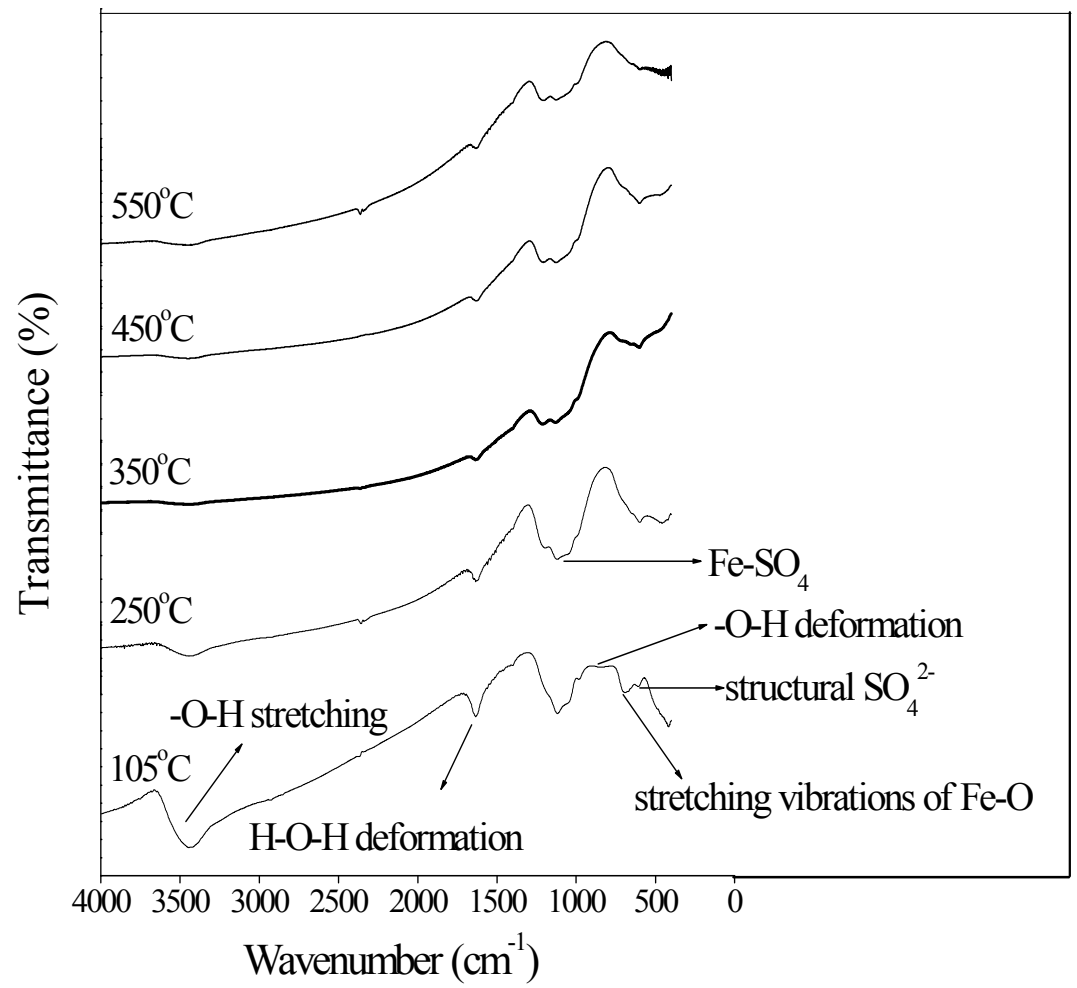

Figure 2. Fourier transform infrared (FTIR) spectroscopy of bio-schwertmannite before and after heating.

In untreated bio-schwertmannite, the intense absorption peak observed in the region of 2900-3700 $\mathrm{cm}^{-1}$ can be attributed to $-\mathrm{O}-\mathrm{H}$ stretching [23]. Furthermore, the band observed at $1635 \mathrm{~cm}^{-1}$ is the deformation of $\mathrm{H}-\mathrm{O}-\mathrm{H}$ [23], and the intense peaks shown at 1000-1250 $\mathrm{cm}^{-1}$ represent the strong $\mathrm{SO}_{4}$ stretching vibration, which can be attributed to the formation of an $\mathrm{Fe}-\mathrm{SO}_{4}$ bridging complex [41]. Related features due to the presence of structural $\mathrm{SO}_{4}$ include bands at $981 \mathrm{~cm}^{-1}$ and $607 \mathrm{~cm}^{-1}$ [42]. The peak at $692 \mathrm{~cm}^{-1}$ and broad absorption peak at $860 \mathrm{~cm}^{-1}$ can be attributed to $\mathrm{Fe}-\mathrm{O}$ stretching and $-\mathrm{O}-\mathrm{H}$ deformation [42].

Spectra shown in Figure 2 for heated bio-schwertmannite show that the peaks corresponding to the deformation of $\mathrm{H}-\mathrm{O}-\mathrm{H}\left(\right.$ at $1635 \mathrm{~cm}^{-1}$ ), $-\mathrm{O}-\mathrm{H}$ stretching (at $2900-3700 \mathrm{~cm}^{-1}$ ), and -O-H deformation (at $860 \mathrm{~cm}^{-1}$ ), gradually weakened (albeit only slightly) when the heating temperature increased to $350{ }^{\circ} \mathrm{C}$. In addition, the band for structural $\mathrm{SO}_{4}{ }^{2-}$ also showed a slight weakening trend. Adsorbed water molecules in a material are known to be removed upon heating at $105^{\circ} \mathrm{C}$. Sun et al. [40] reported that structural water in bio-schwertmannite can be removed when the heating temperature exceeds $120^{\circ} \mathrm{C}$. A comparison of Figures 1 and 2 leads to the conclusion that the weight loss of bio-schwertmannite during heating at $250-550{ }^{\circ} \mathrm{C}$ was due mainly to the loss of structural water and $-\mathrm{O}-\mathrm{H}$ groups.

X-ray diffraction was used to determine the mineral phase and identify the crystalline mineral and amorphous mineral. The XRD patterns of untreated and heat-treated bio-schwertmannite are shown in Figure 3. Because schwertmannite is a poorly crystalline Fe(III)-oxyhydroxy-sulfate mineral [21], the characteristic peaks expressed in bio-schwertmannite XRD patterns are broad peaks [43,44]. The XRD pattern of schwertmannite has eight broad peaks (JCPDS, PDF 47-1775) and these occur 
at $2 \theta=18.24^{\circ}, 26.27^{\circ}, 35.16^{\circ}, 39.49^{\circ}, 46.54^{\circ}, 55.30^{\circ}, 61.34^{\circ}$, and $63.68^{\circ}$. The typical broad peaks at $2 \theta=26.27^{\circ}, 35.16^{\circ}, 55.30^{\circ}$, and $61.34^{\circ}$ are the most easily identified for schwertmannite.

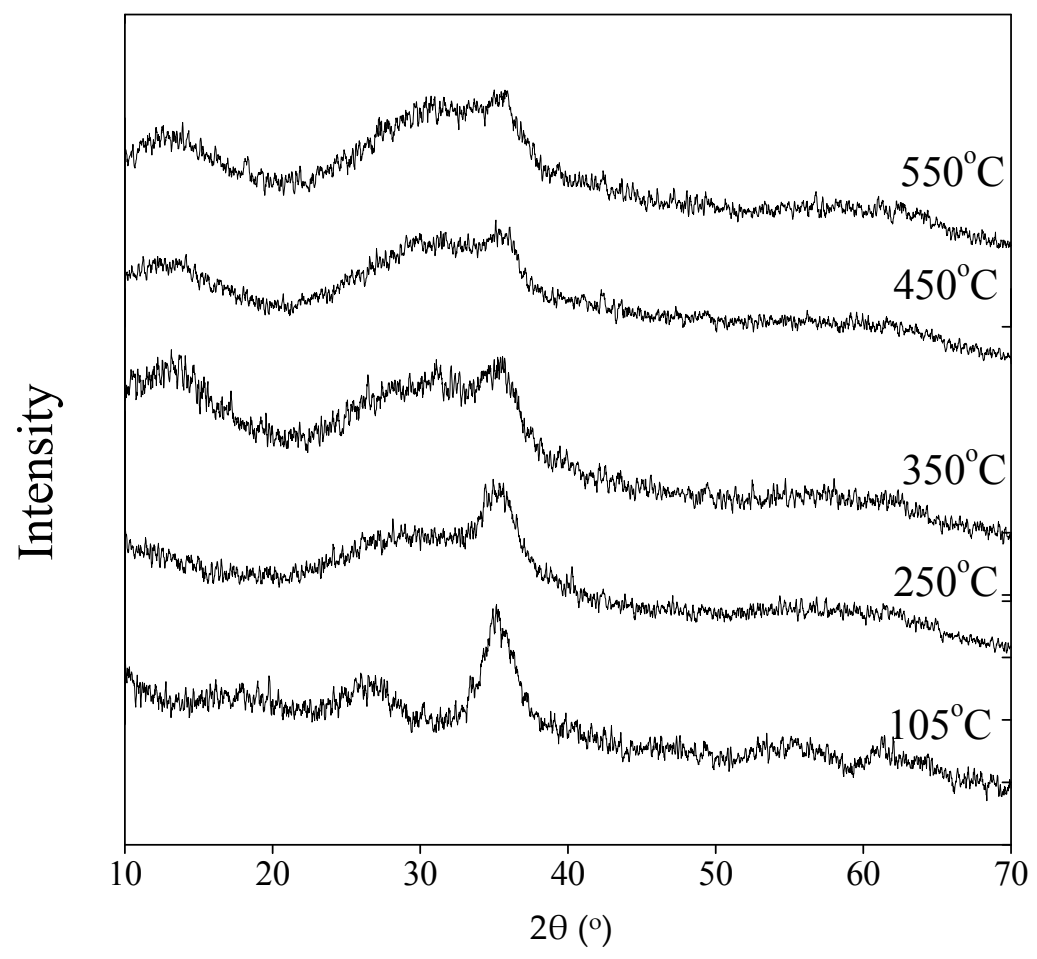

Figure 3. The X-ray diffraction (XRD) patterns of bio-schwertmannite before and after heating.

The results in Figure 3 show that the XRD patterns were similar for untreated bio-schwertmannite dried at $105{ }^{\circ} \mathrm{C}$ and for material heated at $250{ }^{\circ} \mathrm{C}$. In other words, the mineral phase of bio-schwertmannite did not greatly change when the heating temperature increased to $250{ }^{\circ} \mathrm{C}$. However, the intensity of the typical broad peaks at $2 \theta=35.16^{\circ}$ in XRD patterns for bio-schwertmannite heated at $350-550^{\circ} \mathrm{C}$ were relatively weak compared to those for untreated bio-schwertmannite and for the material when heated to $250^{\circ} \mathrm{C}$. Furthermore, a broad peak at $2 \theta \approx 30^{\circ}-35^{\circ}$ appeared obviously in bio-schwertmannite heated at $350-550{ }^{\circ} \mathrm{C}$ but was not observed in untreated bio-schwertmannite or weakly presented in that heated to $250^{\circ} \mathrm{C}$. This additional peak indicated that some bio-schwertmannite underwent obvious phase transformation to an another amorphous or nanocrystalline phase at $350-550{ }^{\circ} \mathrm{C}$ even though schwertmannite remained in the main phase. In addition, it should be pointed out that this amorphous or nanocrystalline material may be the two-line ferrihydrite, which also can adsorb arsenic(III) and arsenic(V) [45,46]. Jiang et al. [45] reported that the chemical synthesized two-line ferrihydrite has a broad characteristic peak at $2 \theta=34^{\circ}$. Therefore, the bio-schwertmannite may have changed to two-line ferrihydrite under heating conditions, especially when the heating temperature reached above $350{ }^{\circ} \mathrm{C}$.

\subsection{Morphology, Specific Surface Area, and Total Pore Volume of Bio-Schwertmannite}

Field-emission scanning electron microscopy (SEM) is the main method for observing mineral morphology [30,47]. The SEM-determined morphology, specific surface area (SSA), and total pore volume of bio-schwertmannite before and after heating are shown in Figure 4. 

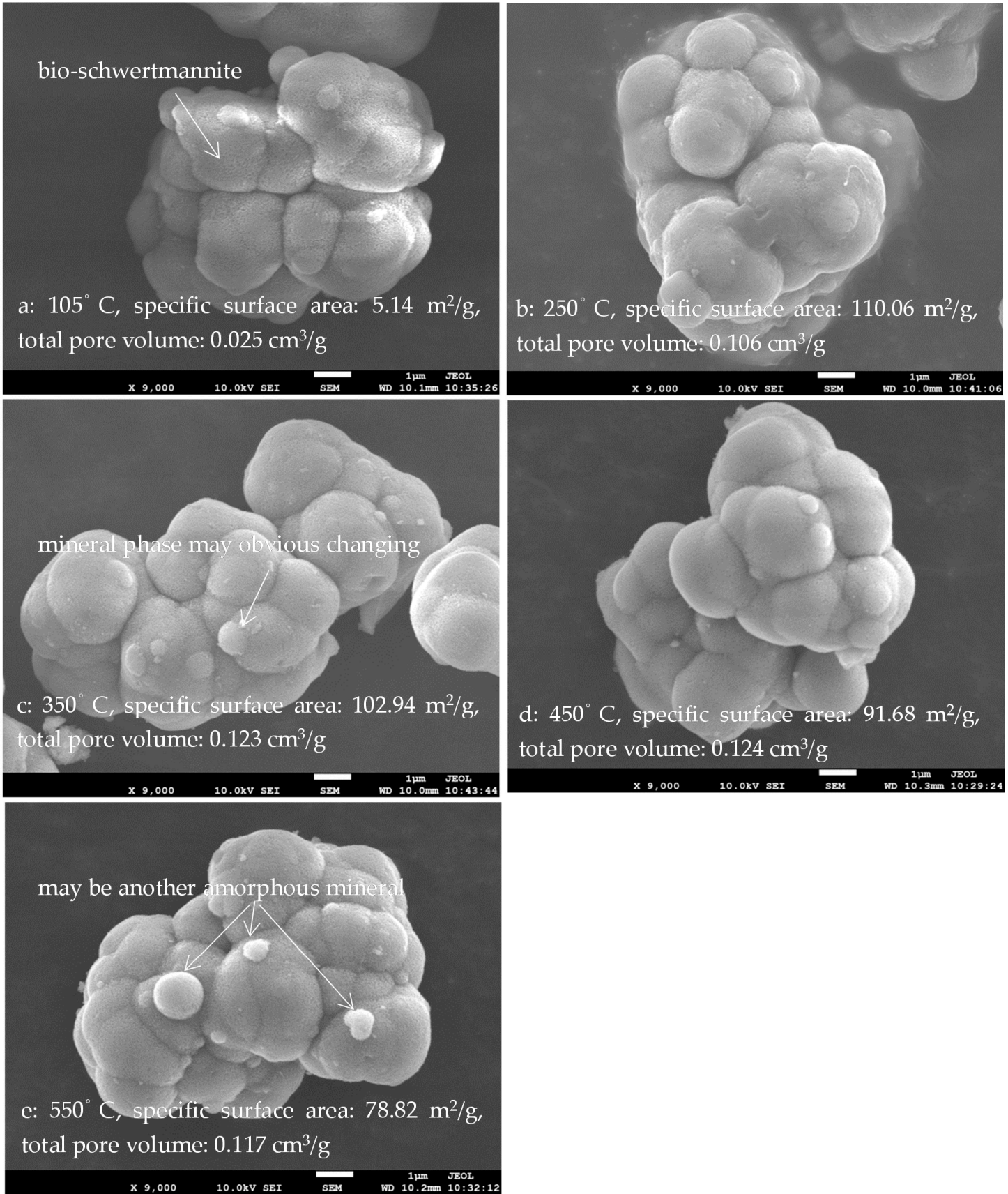

Figure 4. Morphology, specific surface area, and total pore volume of bio-schwertmannite before and after heating.

Untreated bio-schwertmannite clearly exhibited a structure comprised of aggregated homogeneous spherical particles (approximately 2-3 $\mu \mathrm{m}$ diameter) with coarse pores. These characteristics of bio-schwertmannite particles produced in this study were in agreement with the description by Gagliano et al. [48] of naturally occurring schwertmannite collected from a constructed wetland treating mine drainage. After heating at $250-550{ }^{\circ} \mathrm{C}$, the morphology of heated bio-schwertmannite showed no great difference compared to untreated bio-schwertmannite, but the bio-schwertmannite surface may have presented another mineral phase. This phenomenon can be confirmed from the results showed in Figure 3. The aggregation of individual bio-schwertmannite spherical particles showed no obvious change after heating at $250-550{ }^{\circ} \mathrm{C}$. These results indicate that the aggregation of 
bio-schwertmannite particles was not only due to the EPS secreted by A. ferrooxidans or A. ferrooxidans cells. Chemical bonds between bio-schwertmannite particles also play a role in the aggregation, and these bonds are not easily broken by heating at $250-550{ }^{\circ} \mathrm{C}$. In other words, the EPS of $A$. ferrooxidans or A. ferrooxidans cells promotes the production of chemical bonds between bio-schwertmannite particles, and is not the only aggregation effect.

Although the morphology of heated bio-schwertmannite was not great changed by heating, the SSA and total pore volume were significantly increased by heating. The SSA and total pore volume of untreated bio-schwertmannite were 5.14 and $0.025 \mathrm{~cm}^{3} / \mathrm{g}$, respectively. Previous researchers have found that the SSA of bio-synthesized schwertmannite varied from $\sim 3$ to $\sim 50 \mathrm{~m}^{2} / \mathrm{g}[15,27,31,33]$. However, the SSA and total pore volume sharply increased to 110.06 and $0.106 \mathrm{~cm}^{3} / \mathrm{g}$, respectively, in bio-schwertmannite heated at $250{ }^{\circ} \mathrm{C}$. The corresponding relationship between SSA and total pore volume for $250^{\circ} \mathrm{C}$-heated bio-schwertmannite in this study were similar to findings by Dou et al. [49] who chemically synthesized schwertmannite using $\mathrm{FeCl}_{3}$ and $\mathrm{Na}_{2} \mathrm{SO}_{4}$; the material had an SSA and total pore volume of 206.1 and $0.22 \mathrm{~cm}^{3} / \mathrm{g}$, respectively. Compared with that for bio-schwertmannite heated at $250{ }^{\circ} \mathrm{C}$, the SSA of bio-schwertmannite heated at $350-550{ }^{\circ} \mathrm{C}$ sharply decreased while the total pore volume increased. For example, the SSA decreased to $78.82 \mathrm{~m}^{2} / \mathrm{g}$ and the total pore volume increased to $0.117 \mathrm{~cm}^{3} / \mathrm{g}$ in bio-schwertmannite heated at $550{ }^{\circ} \mathrm{C}$. Thus, the SSA of heated bio-schwertmannite reached a maximum value in the $250{ }^{\circ} \mathrm{C}$ heat treatment.

For explicating the influence factor of specific surface area in $250{ }^{\circ} \mathrm{C}$ heated bio-schwertmannite, a chemically synthesized schwertmannite was prepared by chemically oxidizing $\mathrm{FeSO}_{4}$ with $\mathrm{H}_{2} \mathrm{O}_{2}$ in this study. The SSA of the chemical synthesized schwertmannite was $3.45 \mathrm{~m}^{2} / \mathrm{g}$. However, when the schwertmannite was heated at $250{ }^{\circ} \mathrm{C}$ the SSA remained almost constant $\left(3.47 \mathrm{~m}^{2} / \mathrm{g}\right)$, although the weight loss reached $19.04 \%$ due to the loss of $\mathrm{OH}^{-}$groups and structural water. These results indicated that the loss of $\mathrm{OH}^{-}$groups and structural water has no influence on the SSA of schwertmannite during heating. In other words, the larger SSA of bio-schwertmannite heated at $250{ }^{\circ} \mathrm{C}$ in the current study was due to the removal of EPS secreted by $A$. ferrooxidans and dead $A$. ferrooxidans cells. Furthermore, the results shown in Figures 1 and 4 indicated that the TOC content has a significant negative correlation $\left(R^{2}=0.95\right)$ with the total pore volume. The removal of EPS secreted by $A$. ferrooxidans and A. ferrooxidans cells could significantly increase the total pore volume of bio-schwertmannite. As noted, the SSA of heated bio-schwertmannite gradually decreased when the heating temperature increased from 350 to $550{ }^{\circ} \mathrm{C}$, although there was no obvious change in total pore volume. This result may be regulated by the mineral phase changed when the heating temperature increased from 350 to $550{ }^{\circ} \mathrm{C}$.

\subsection{Specific Surface Area and Pore Volume Distribution among Micropores, Mesopores, and Macropores in Bio-Schwertmannite}

The SSA of adsorbents results mainly from different types of pores [50]. In general, the pores in materials can be classified as micropores (diameter $<2 \mathrm{~nm}$ ), mesopores (diameter 2-50 nm), and macropores (diameter $>50 \mathrm{~nm}$ ) [51]. The distribution of SSA and pore volume among micropores, mesopores, and macropores in bio-schwertmannite is exhibited in Figure 5. In untreated bio-schwertmannite (dried at $105^{\circ} \mathrm{C}$ ), 58.2\% and $41.2 \%$ of total SSA, $32.0 \%$ and $68.0 \%$ of total pore volume were contributed from mesopores and macropores, respectively. However, micropores, mesopores, and macropores contributed $35.1 \%, 26.2 \%$, and $38.7 \%$, respectively, of the total SSA, and $23.6 \%, 33.0 \%$, and $43.4 \%$, respectively, of the total pore volume in bio-schwertmannite heated at $250{ }^{\circ} \mathrm{C}$. When heating increased to $350-550{ }^{\circ} \mathrm{C}$, nearly all of the micropores disappeared from bio-schwertmannite. This result explains the SSA variations described in Section 3.3. In other words, because many micropores disappeared at high heating temperatures, the SSA of bio-schwertmannite decreased gradually from 110.06 to $78.82 \mathrm{~m}^{2} / \mathrm{g}$ while the corresponding total pore volume increased from 0.106 to $0.117 \mathrm{~cm}^{3} / \mathrm{g}$ as the heating temperature increased from 250 to $550{ }^{\circ} \mathrm{C}$. Furthermore, the TOC content and weight loss of bio-schwertmannite nearly stabilized (Figure 1) when bio-schwertmannite heating exceeded $350^{\circ} \mathrm{C}$. Therefore, the gradual decrease in the SSA of 
heated bio-schwertmannite as heating temperature increased from 350 to $550{ }^{\circ} \mathrm{C}$ (Figure 4) may have been caused by the mineral phase transformation (Figure 2). This phase transformation also could have caused the reduction of macropore volume and the amount of SSA contributed by macropores.
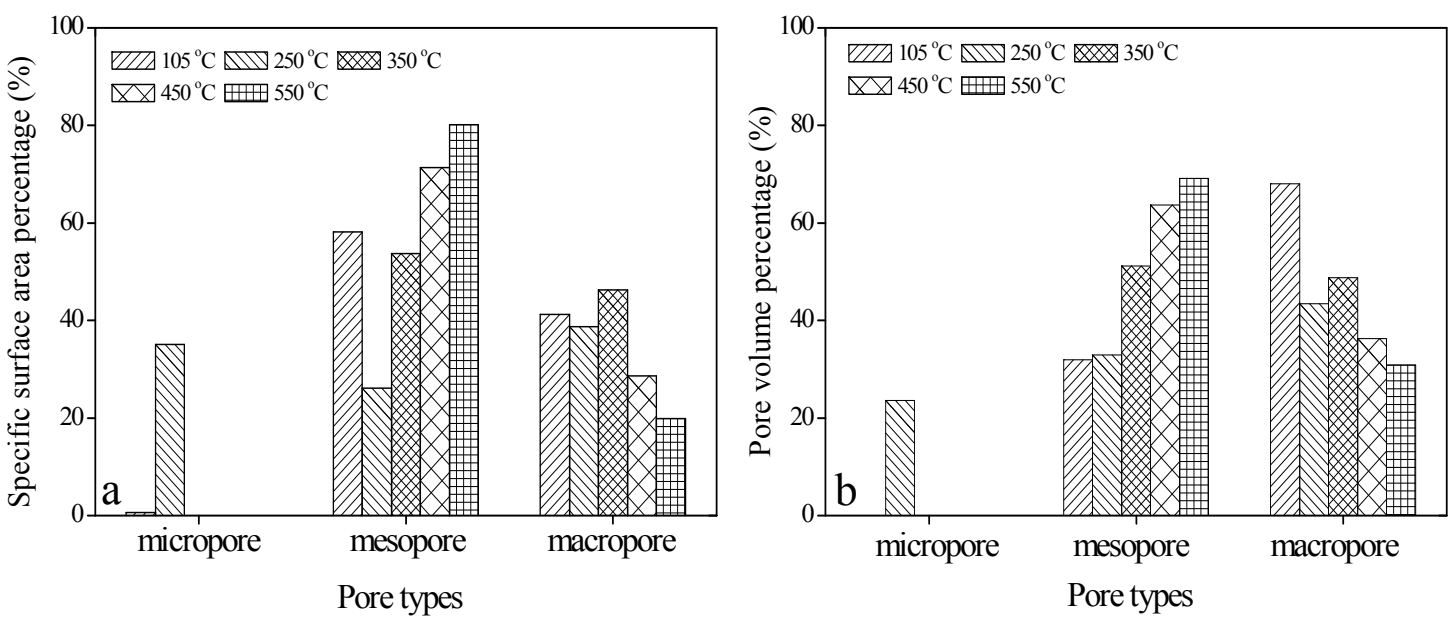

Figure 5. Specific surface area (a) and pore volume distribution of micropore, mesopore, and macropore in bio-schwertmannite (b) before and after heating.

\subsection{Arsenic(III) Removal Efficiency of Bio-Schwertmannite}

Representative samples of untreated bio-schwertmannite and of material heated at 250 and $550{ }^{\circ} \mathrm{C}$ were used to study the arsenic(III) removal efficiency of the bio-schwertmannite before and after heating (Figure 6).

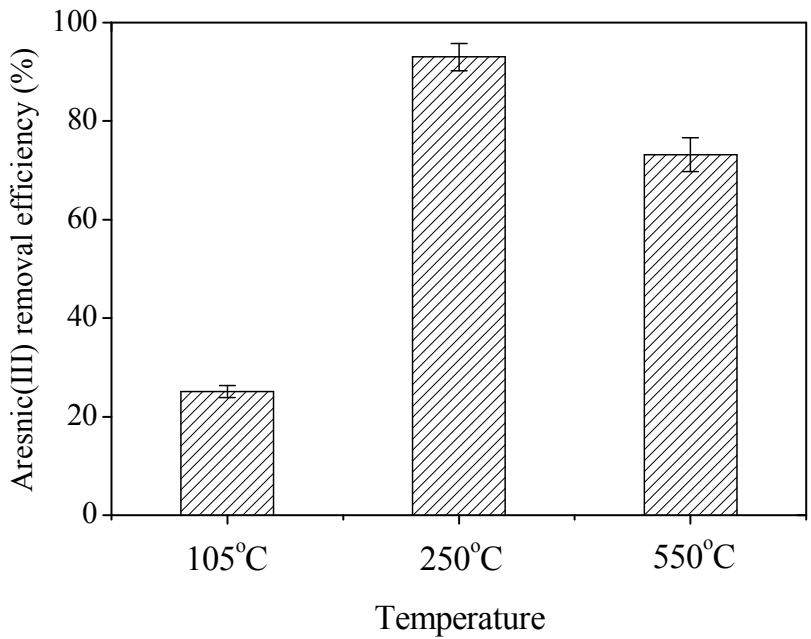

Figure 6. Arsenic(III) removal efficiency of bio-schwertmannite before and after heating.

The arsenic(III) removal efficiency of untreated bio-schwertmannite $(0.25 \mathrm{~g} / \mathrm{L}$ in a solution initially containing $1 \mathrm{mg} / \mathrm{L}$ arsenic(III) at $\mathrm{pH} \sim 7.5$ ) was $25.1 \%$ ( $4 \mathrm{~h}$ reaction duration). However, this removal efficiency increased to $93.0 \%$ for bio-schwertmannite heated at $250{ }^{\circ} \mathrm{C}$, but was only $73.2 \%$ for bio-schwertmannite heated at $550{ }^{\circ} \mathrm{C}$. In other words, $13.4,49.7$, and $39.1 \mu \mathrm{mol}$ of arsenic(III) can be removed per $g$ of untreated $250{ }^{\circ} \mathrm{C}$, or $550{ }^{\circ} \mathrm{C}$ heated bio-schwertmannite, respectively. These results highlighted that the SSA of bio-schwertmannite determined the arsenic(III) removal capacity. As shown in Section 3.2, some $\mathrm{OH}^{-}$groups of bio-schwertmannite were removed when the heating temperature reached $250-550{ }^{\circ} \mathrm{C}$. However, $\mathrm{OH}^{-}$groups on the schwertmannite surface can exchange their 
ligands with arsenic(III) species and improve the arsenic(III) removal efficiency [13]. Therefore, it is inferred that the arsenic(III) removal efficiency of heated bio-schwertmannite is mainly due to ligand exchange between $\mathrm{SO}_{4}{ }^{2-}$ and arsenic(III) because the $\mathrm{SO}_{4}{ }^{2-}$ groups remained intact in heated bio-schwertmannite at heating temperatures between 250 and $550{ }^{\circ} \mathrm{C}$ (Figure 2). It should be noted that part of arsenic(III) may adsorb on the remainder organic matter through complexing action when $250{ }^{\circ} \mathrm{C}$ heated bio-schertmannite is used as an adsorbent for arsenic(III) removal. In addition, adsorbent regeneration is a quite important issue from an adsorbent life cycle perspective. After arsenic(III) adsorption, arsenic(III)-bearing bio-schwertmannite could be regenerated by $1.0 \mathrm{~mol} / \mathrm{L} \mathrm{NaOH}$ solution, and more than $80 \%$ of arsenic(III) adsorbed on the surface of bio-schwertmannite could be released after three successive regenerations [52].

\section{Conclusions}

Bio-schwertmannite can be bio-synthesized by A. ferrooxidans LX5 in $60 \mathrm{~h}$, and the SSA of the resulting material is relatively small $\left(5.14 \mathrm{~m}^{2} / \mathrm{g}\right)$. However, the SSA of bio-schwertmannite can be increased significantly (20-fold) by heating the material at $250{ }^{\circ} \mathrm{C}$. Heating results in the removal of EPS secreted by $A$. ferrooxidans and A. ferrooxidans cells. Correspondingly, heating bio-schwertmannite at $250{ }^{\circ} \mathrm{C}$ increases the material's arsenic(III) removal efficiency (by 2.68 times in this study) due in part to increased SSA. If heating temperature increases from 350 to $550{ }^{\circ} \mathrm{C}$, an obvious transformation in the mineral phase of bio-schwertmannite occurs. In this study, the SSA of bio-schwertmannite heated at 350 and $550{ }^{\circ} \mathrm{C}$ decreased to 102.94 and $78.82 \mathrm{~m}^{2} / \mathrm{g}$, respectively, from a maximum of $110.06 \mathrm{~m}^{2} / \mathrm{g}$ achieved by heating at $250{ }^{\circ} \mathrm{C}$. Thus, while heating bio-schwertmannite at $250{ }^{\circ} \mathrm{C}$ improves the material's properties as an absorbent for arsenic(III) removal, heating at $350-550{ }^{\circ} \mathrm{C}$ causes these properties to deteriorate. The outcomes of this study provide guidance for the preparation and effective use of bio-schwertmannite as an absorbent for removing arsenic(III) from contaminated groundwater. The details of mineral phase changes and whether the arsenic(III) can be partly oxidized to $\mathrm{As}(\mathrm{V})$ by dried and heated bio-schwertmannite will be the focus of further study.

Acknowledgments: This work was supported by the National Natural Science Foundation of China (21637003, 21407102), the Natural Science Foundation of Shanxi Province, China (2015011022), and the Program for the Top Young Innovative Talents of Shanxi Agricultural University (TYIT 201405).

Author Contributions: X.Q., L.Z. and F.L. conceived and designed the experiments; X.Q. performed the experiments; X.Q. and L.L. analyzed the data; J.S., Y.G., Y.G. and W.F. contributed reagents/materials/analysis tools; X.Q. wrote the paper.

Conflicts of Interest: The authors declare no conflict of interest.

\section{References}

1. Li, P.; Wu, J.; Qian, H. Hydrochemical appraisal of groundwater quality for drinking and irrigation purposes and the major influencing factors: A case study in and around Hua County, China. Arab. J. Geosci. 2016, 9, 1-17. [CrossRef]

2. Das, S.; Sudipta, B.S.; Lahan, P.; Jyoti, B.; Mridul, C.; Barooah, M. Groundwater arsenic contamination in north eastern states of India. J. Environ. Res. Dev. 2015, 9, 621-632.

3. Shrestha, S.M.; Rijal, K.; Pokhrel, M.R. Assessment of Arsenic Contamination in Deep Groundwater Resources of the Kathmandu Valley, Nepal. J. Geosci. Environ. Prot. 2015, 3, 79-89. [CrossRef]

4. Bulka, C.M.; Jones, R.M.; Turyk, M.E.; Stayner, L.T.; Argos, M. Arsenic in drinking water and prostate cancer in Illinois counties: An ecologic study. Environ. Res. 2016, 148, 450-456. [CrossRef] [PubMed]

5. Mohan, D.; Pittman, C.U., Jr. Arsenic removal from water/wastewater using adsorbents-A critical review. J. Hazard. Mater. 2007, 142, 1-53. [CrossRef] [PubMed]

6. Liaw, J.; Marshall, G.; Yuan, Y.; Ferreccio, C.; Steinmaus, C.; Smith, A.H. Increased childhood liver cancer mortality and arsenic in drinking water in Northern Chile. Cancer Epidemiol. Biomark. Prev. 2008, 17, 1982-1987. [CrossRef] [PubMed] 
7. Ahamed, S.; Sengupta, M.K.; Mukherjee, A.; Hossain, M.A.; Das, B.; Nayak, B.; Pal, A.; Mukherjee, S.C.; Pati, S.; Dutta, R.N.; et al. Arsenic groundwater contamination and its health effects in the state of Uttar Pradesh (UP) in upper and middle Ganga plain, India: A severe danger. Sci. Total Environ. 2006, 370, 310-322. [CrossRef] [PubMed]

8. He, J.; Ma, T.; Deng, Y.M.; Yang, H.; Wang, Y.X. Environmental geochemistry of high arsenic groundwater at western Hetao plain, Inner Mongolia. Front. Earth Sci. China 2008, 3, 63-72. [CrossRef]

9. George, C.M.; Zheng, Y.; Graziano, J.H.; Rasul, S.B.; Hossain, Z.; Mey, J.L.; Geen, A.V. Evaluation of an arsenic test kit for rapid well screening in Bangladesh. Environ. Sci. Technol. 2012, 46, 11213-11219. [CrossRef] [PubMed]

10. Chakraborti, D.; Rahman, M.M.; Ahamed, S.; Dutta, R.N.; Pati, S.; Mukherjee, S.C. Arsenic groundwater contamination and its health effects in Patna district (capital of Bihar) in the middle Ganga plain, India. Chemosphere 2016, 152, 520-529. [CrossRef] [PubMed]

11. Xie, X.J.; Wang, Y.X.; Su, C.L.; Liu, H.Q.; Duan, M.Y.; Xie, Z.M. Arsenic mobilization in shallow aquifers of Datong Basin: Hydrochemical and mineralogical evidences. J. Geochem. Explor. 2008, 98, 107-115. [CrossRef]

12. Sarkar, A.; Paul, B. The global menace of arsenic and its conventional remediation-A critical review. Chemosphere 2006, 158, 37-49. [CrossRef] [PubMed]

13. Liao, Y.H.; Liang, J.R.; Zhou, L.X. Adsorptive removal of As(III) by biogenic schwertmannite from simulated As-contaminated groundwater. Chemosphere 2011, 83, 295-301. [CrossRef] [PubMed]

14. Roy, P.K.; Choudhury, M.R.; Ali, M.A. As(III) and As(V) Adsorption on Magnetite Nanoparticles: Adsorption Isotherms: Effect of $\mathrm{pH}$ and phosphate, and Adsorption Kinetics. Int. J. Chem. Environ. Eng. 2013, 4, 55-63.

15. Song, J.; Jia, S.Y.; Ren, H.T.; Wu, S.H.; Han, X. Application of a high-surface-area schwertmannite in the removal of arsenate and arsenite. Int. J. Environ. Sci. Technol. 2015, 12, 1559-1568. [CrossRef]

16. Lin, T.F.; Wu, J.K. Adsorption of arsenite and arsenate within activated alumina grains: Equilibrium and kinetics. Water Res. 2001, 35, 2049-2057. [CrossRef]

17. Dodbiba, G.; NuKaya, T.; Kamioka, Y.; Tanimura, Y.; Fujita, T. Removal of arsenic from wastewater using iron compound: Comparing two different types of adsorbents in the context of LCA. Resour. Conserv. Recycl. 2009, 53, 688-697. [CrossRef]

18. Kumar, A.S.K.; Jiang, S.J. Chitosan-functionalized graphene oxide: A novel adsorbent an efficient adsorption of arsenic from aqueous solution. J. Environ. Chem. Eng. 2016, 4, 1698-1713. [CrossRef]

19. Zhu, N.Y.; Yan, T.M.; Qiao, J.; Cao, H.L. Adsorption of arsenic, phosphorus and chromium by bismuth impregnated biochar: Adsorption mechanism and depleted adsorbent utilization. Chemosphere 2016, 164, 32-40. [CrossRef] [PubMed]

20. Namor, A.F.D.; Hakawati, N.; Hamdan, W.A.; Soualhi, R.; Korfali, S.; Valiente, L. Calix[4] pyrrole for the removal of arsenic(III) and arsenic(V) from water. J. Hazard. Mater. 2017, 326, 61-68. [CrossRef] [PubMed]

21. Strosnider, W.H.J.; Winfrey, B.K.; Peer, R.A.M.; Nairn, R.W. Passive co-treatment of acid mine drainage and sewage: Anaerobic incubation reveals a regeneration technique and further treatment possibilities. Ecol. Eng. 2013, 61, 268-273. [CrossRef]

22. Bigham, J.M.; Schwertmann, U.; Carlson, L.; Murad, E. A poorly crystallized oxyhydroxysulfate of iron formed by bacterial oxidation of Fe(II) in acid mine waters. Geochim. Cosmochim. Acta 1990, 54, 2743-2758. [CrossRef]

23. Gan, M.; Sun, S.J.; Zheng, Z.H.; Tang, H.J.; Sheng, J.R.; Zhu, J.Y.; Liu, X.X. Adsorption of Cr(VI) and Cu(II) by $\mathrm{AlPO}_{4}$ modified biosynthetic schwertmannite. Appl. Surf. Sci. 2015, 356, 986-997. [CrossRef]

24. Nordstrom, D.K.; Alpers, C.N. Geochemistry of acid mine waters. Soc. Econ. Geol. 1999, 6A, 133-160.

25. Fernandez-Martinez, A.; Timon, V.; Román-Ross, G.; Cuello, G.J.; Daniels, J.E.; Ayora, C. The structure of schwertmannite, a nanocrystalline iron oxyhydroxysulfate. Am. Mineral. 2010, 95, 1312-1322. [CrossRef]

26. Antelo, J.; Fiol, S.; Gondar, D.; López, R.; Arce, F. Comparison of arsenate, chromate and molybdate binding on schwertmannite: Surface adsorption vs. anion-exchange. J. Colloid Interface Sci. 2012, 386, 338-343. [CrossRef] [PubMed]

27. Liu, F.W.; Zhou, J.; Zhang, S.S.; Liu, L.L.; Zhou, L.X.; Fan, W.H. Schwertmannite synthesis through ferrous ion chemical oxidation under different $\mathrm{H}_{2} \mathrm{O}_{2}$ supply rates and its removal efficiency for arsenic from contaminated groundwater. PLoS ONE 2015, 10, e0138891. [CrossRef] [PubMed] 
28. Bigham, J.M.; Carlson, L.; Murad, E. Schwertmannite, a new iron oxyhydroxysulfate from pyhäsalmi, Finland, and other localities. Mineral. Mag. 1994, 58, 641-648. [CrossRef]

29. Wang, X.; Gu, C.; Feng, X.; Zhu, M. Sulfate local coordination environment in schwertmannite. Environ. Sci. Technol. 2015, 49, 10440-10448. [CrossRef] [PubMed]

30. Paikaray, S.; Göttlicher, J.; Peiffer, S. As(III) retention kinetics, equilibrium and redox stability on biosynthesized schwertmannite and its fate and control on schwertmannite stability on acidic $(\mathrm{pH} 3.0)$ aqueous exposure. Chemosphere 2012, 86, 557-564. [CrossRef] [PubMed]

31. Liao, Y.H.; Zhou, L.X.; Liang, J.R.; Xiong, H.X. Biosynthesis of schwertmannite by Acidithiobacillus ferrooxidans cell suspensions under different pH condition. Mater. Sci. Eng. C 2009, 29, 211-215. [CrossRef]

32. Liang, J.R.; Li, Z.Y.; Liu, F.W.; Zhou, L.X. Mineralogical characteristics of biogenic schwertmannite amended with different pretreatment methods and the effects on As(III) adsorption. Environ. Sci. 2012, 33, 3605-3612.

33. Paikaray, S.; Göttlicher, J.; Peiffer, S. Removal of As(III) from acidic waters using schwertmannite: Surface speciation and effect of synthesis pathway. Chem. Geol. 2011, 283, 134-142. [CrossRef]

34. Yu, R.L.; Ou, Y.; Tan, J.X.; Wu, F.D.; Sun, J.; Miao, L.; Zhong, D.L. Effect of EPS on adhesion of Acidithiobacillus ferrooxidans on chalcopyrite and pyrite mineral surfaces. Chin. J. Nonferr. Met. 2011, 21, 407-412. [CrossRef]

35. Liu, F.W.; Zhou, J.; Zhou, L.X.; Zhang, S.S.; Liu, L.L.; Wang, M. Effect of neutralized solid waste generated in lime neutralization on the ferrous ion bio-oxidation process during acid mine drainage treatment. J. Hazard. Mater. 2015, 299, 404-411. [CrossRef] [PubMed]

36. Zhu, P.N.; Nair, A.S.; Yang, S.Y.; Peng, S.J.; Elumalai, N.K.; Ramakrishna, S. Rice grain-shaped TiO $2-\mathrm{MWCNT}^{-}$ composite-A functional material with a novel morphology for dye-sensitized solar cells. J. Photochem. Photobiol. A 2012, 231, 9-18.

37. Zhou, K.; Zhang, W.Y.; Pan, H.M.; Li, J.H.; Yue, H.D.; Wu, L.F. Adaptation of spherical multicellular magnetotactic prokaryotes to the geochemically variable habitat of an intertidal zone. Environ. Microbiol. 2013, 15, 1595-1605. [CrossRef] [PubMed]

38. Liu, X.; Duan, T.; Han, Y.; Jia, X.; Chen, H. On-line solid phase extraction-hydride generation atomic fluorescence spectrometric determination of trace arsenic in high purity antimony(III) oxide. J. Anal. At. Spectrom. 2009, 25, 206-209. [CrossRef]

39. Wang, H.M.; Bigham, J.M.; Tuovinen, O.H. Formation of schwertmannite and its transformation to jarosite in the presence of acidophilic iron-oxidizing microorganisms. Mater. Sci. Eng. C 2006, 26, 588-592. [CrossRef]

40. Sun, H.F.; Zhao, F.H.; Cong, Z.Y.; Yue, M.; Ren, D.Y. The mineral Schwertmannite found in China and its characteristics. Acta Mineral. Sin. 2006, 26, 38-42.

41. Zhang, S.L.; Jia, S.Y.; Yu, B.; Liu, Y.; Wu, S.H.; Han, X. Sulfidization of As(V)-containing schwertmannite and its impact on arsenic mobilization. Chem. Geol. 2016, 420, 270-279. [CrossRef]

42. Goswami, A.; Purkait, M.K. Removal of fluoride from drinking water using nanomagnetite aggregated schwertmannite. J. Water Process Eng. 2014, 1, 91-100. [CrossRef]

43. Schwertmann, U.; Bigham, J.M.; Murad, E. The first occurrence of schwertmannite in a natural stream environment. Eur. J. Mineral. 1995, 7, 547-552.

44. Bigham, J.M.; Schwertmann, U.; Pfab, G. Influence of $\mathrm{pH}$ on mineral speciation in a bioreactor simulating acid mine drainage. Appl. Geochem. 1996, 11, 845-849. [CrossRef]

45. Jiang, X.L.; Peng, C.J.; Fu, D.; Chen, Z.; Shen, L.; Li, Q.B.; Ouyang, T.; Wang, Y.P. Removal of arsenate by ferrihydrite via surface complexation and surface precipitation. Appl. Surf. Sci. 2015, 353, 1087-1094. [CrossRef]

46. Zhu, J.; Pigna, M.; Cozzolino, V.; Caporale, A.G.; Violante, A. Sorption of arsenite and arsenate on ferrihydrite: Effect of organic and inorganic ligands. J. Hazard. Mater. 2011, 189, 564-571. [CrossRef] [PubMed]

47. Wang, J.L.; Hsieh, T.Y.; Yang, P.Y.; Hwang, C.C.; Shye, D.C.; Lee, I.C. Oxygen annealing effect on field-emission characteristics of hydrothermally synthesized Al-doped ZnO nanowires. Surf. Coat. Technol. 2013, 231, 423-427. [CrossRef]

48. Gagliano, W.B.; Brill, M.R.; Bigham, J.M.; Jones, F.S.; Traina, S.J. Chemistry and mineralogy of ochreous sediments in a constructed mine drainage wetland. Geochim. Cosmochim. Acta 2004, 68, 2119-2128. [CrossRef]

49. Dou, X.M.; Mohan, D.; Pittman, C.U., Jr. Arsenate adsorption on three types of granular schwertmannite. Water Res. 2013, 47, 2938-2948. [CrossRef] [PubMed] 
50. Bagheri, S.; Hir, Z.A.M.; Yousefi, A.T.; Hamid, S.B.A. Progress on mesoporous titanium dioxide: Synthesis, modification and applications. Microporous Mesoporous Mater. 2015, 218, 206-222. [CrossRef]

51. Chen, Y.H.; Wu, Q.L.; Ning, P.; Gong, J.H.; Ding, P. Rayon-based activated carbon fibers treated with both alkali metal salt and Lewis acid. Microporous Mesoporous Mater. 2008, 109, 138-146. [CrossRef]

52. Xie, Y.; Zhou, L.X. Arsenite removal from simulated groundwater by biogenic schwertmannite: A column trial. Pedosphere 2013, 23, 402-408. [CrossRef]

(C) 2017 by the authors; licensee MDPI, Basel, Switzerland. This article is an open access article distributed under the terms and conditions of the Creative Commons Attribution (CC-BY) license (http:/ / creativecommons.org/licenses/by/4.0/). 